Intermedia International e-Journal, Spring - June - 2020, 7 (12)

*DOI NO: 10.21645/intermedia.2020.67 *Submit Date:25.04.2020 $\quad$ *Acceptance Date: 23.06.2020 $\quad$ *ISSN:2149-3669

\title{
THE ROLE OF PRODUCT COMMUNICATION IN CONSUMER TRUST*1
}

\author{
Tüketici Güveninde Ürün Iletişiminin Rolü \\ Buket DURHAN2 \\ Selcuk University, Faculty of Communication \\ *ORCID: 0000-0002-4736-2290 \\ Assoc. Prof. Duygu AYDIN ${ }^{3}$ \\ Selcuk University, Faculty of Communication, Advertising Department \\ *ORCID: 0000-0002-1088-6672
}

\begin{abstract}
Ürün iletişimi, markaların tüketiciyle etkili diyalog geliştirebilecekleri güçlü bir pazarlama iletişimi uygulamasıdır. Ürüne ait somut ve soyut faydalardan yola çıkılarak ürünün kendisini konuşturmak ve bir mecraya dönüştürmek, tüketicide ürüne ve markaya yönelik güven duygusu oluşturmada değeri artan bir stratejidir. Bu çalışmada ürün iletişimi ile tüketici güveni arasındaki ilişki sorgulanmıştır. Perakende sektöründe gıda kategorisi özelinde yapılan araştırma Bartın il merkezinde bulunan yerel bir süpermarkette 500 kişinin katılımıyla anket yöntemiyle gerçekleştirilmiştir. Elde edilen verilerin, parametrik testler aracılı̆̆ıyla analizi yapılmıştır. Ölçeklere ilişkin değerlendirmeler sürecinde keşfedici faktör analizi uygulanmıştır. Ürün bileşenlerinin ve ambalajın, tüketicilerin ürün seçimlerini etkilediği ve dolayısıyla markaya yönelik gelişen güven boyutunda da etkisi olduğu görülmektedir. Çalışmanın bulguları; ürünün somut özelliklerinin markaya, ürüne ve ambalaja yönelik güven oluşmasında etkili olduğunu ortaya koymaktadır. Ambalajın dikkat çekicilik boyutunun, tüketici güveni üzerinde etkiye sahip olduğu ve marka güveniyle pozitif bir ilişki içerisinde bulunduğu tespit edilmiştir. Alışveriş ortamında ürünle ilgili özel iletişim çalışmalarının, ambalaja yönelik güven ve marka güveninde rol oynadığı ortaya konulmuştur. Ürün iletişimi noktasında vurgulanan güçlü firma mesajı ve ambalajın algılanan kullanım kolaylığı, markaya, ürüne ve ambalaja yönelik güven oluşmasında rol oynamakta ve tüketici güven düzeyini artırmaktadır.
\end{abstract}

Öz

Anahtar Kelimeler: Pazarlama iletişimi, Ürün, Güven, Tüketici

Extended Abstract: Product communication is a powerful marketing communication practice where brands can establish effective dialogue with consumers. Based on the concrete and abstract benefits of the product, displaying the product itself and transforming it into a channel is a strategy of increasing value in creating a sense of trust in the consumer and product. In this study, the relationship between product communication and consumer trust was questioned. The research questions of the study are as follows; What is the relationship between product communication and consumer trust?, Does product package affect consumers' trust in the product?, Do the trusting dimensions of product communication affect brand trust?, Does the trust dimension developed in the context of product communication differ according to the demographic characteristics of consumers?. Food category-specific research in the retail sector was conducted by survey method in a local supermarket in the city center of Bartın (In Turkey) with the participation of 500 people. The construct in this study is designed to relate the relationship between product communication and trust factor according to their dimensions. The independent variable in the study is product communication, and the dependent variable is trust. It is aimed to reveal the direction and significance level of the relationship between the two variables. The data were analyzed by parametric tests. Exploratory factor analysis was applied during the evaluation process of the scales. During the process of data evaluation, t-test, Anova test (One-way), Scheffe test, pearson correlation and regression analysis were used. According to the study findings; the concrete properties of the product (color, shape, size, smell) have been found to be effective in building trust in the brand,

\footnotetext{
* Bu çalışma "Tüketici Güveninde Ürün Illetişiminin Rolü Üzerine Uygulamalı Bir Çalışma” başlıklı yüksek lisans tezinden üretilmiştir.

${ }^{1}$ Makalenin Türü: Araştırma Makalesi

2 yamanbuket1@gmail.com

3 duyguaydin@selcuk.edu.tr
} 
product and package. The relationship between the attractiveness of the package and the fact that it is in the forefront and brand trust in general has been found to be positive and significant. However, it is determined that it does not affect the level of trust in brand, product and package statistically. As a result of the special communication activities related to the product in the shopping environment and the emphasis on product package, a significant relationship was established with brand trust in general level. It increases the level of trust in package and the level of trust among consumers in brand criterion. However, on the factor basis, it has been found that special communication dimension did not affect "the brand intention and reliability" and "trust in the product". The strong company message and the perceived ease of use of the package, which are emphasized at the point of product communication, affect the trust in brand, product and package and increase the level of trust. It has been shown that special communication activities related to the product in the shopping environment affect the trust in package and brand trust. The strong company message highlighted in product communication and perceived ease of use of package affect the trust in brand, product and package and increase the level of consumer trust. It was observed that there was a moderate level of participation in the constant renewal of the package and special communication activities related to the product in a store. The process of change and renewal related to the product and package becomes meaningful for the consumer if it is supported by the communication activities of the brands. The positive side of the package renewal process reveals that the brand actually works hard, making the necessary improvements for its consumers and shows an innovative attitude. Conducting special communication activities related to the product within the store is also relevant to the time spent by the consumer in the store. It is concluded that in-store communication activities affect product-based gains and consumer trust. The product was sold in a special place in the market alone and that the product package was more visible than the advertisements of the brand and the emphasis on the package in the advertisements had a high level of participation. Communication activities and in-store stand movements, which are believed to gain originality to the product attract the attention of consumers. Displaying the product alone in the market attracted the attention of the consumer and according to the results of the research, it has managed to become a trust element. Emphasis on package in advertisements indicates that the consumer is offered a product and package supported by communication efforts. According to the results of the research, the fact that package of the product is displayed at the forefront and the emphasis on the package with the communication efforts seem to have gained the trust of the consumer.

Keywords: Marketing Communication, Product, Trust, Consumer

\section{INTRODUCTION}

Product is the heart of marketing. Brands can communicate strongly by using the product itself.In an increasingly competitive market environment, product-oriented communication offers significant opportunities to attract consumers, particularly at the point of purchase. It is possible to turn the product into an effective medium by talking to the consumer through all the components of the product. The convincing power of product communication becomes even more important given that a significant portion of purchasing decisions are made during the purchase. It also acts as a reminder of the brand's other marketing and communications practices.

Many variables come into play in consumers' purchasing decisions. Tens of variables, which are grouped under the titles such as social, psychological, situational and marketing communication factors, affect the purchasing behavior. All variables that can have an impact on consumer behavior, which starts with the emergence of need and continues through evaluation, purchase and post-purchase processes, also create certain emotions in the consumer mind. "Like " and " trust" are the two most important and intertwined emotion factors. Consumers often purchase products that they trust and like. A marketing approach based on gaining the trust and appreciation of consumers should strongly reflect this strategy in all communication practices. Product communication is a powerful weapon that can transfer the sense of trust to the consumer. The sense of trust created through product communication has the power to reinforce the consumer's sense of trust for all components of the brand.

Gaining consumer trust through product communication is the essence of this study. In this study in which the relationship between product communication and consumer trust is questioned, the dimensions that play a role in product communication in retail sector are revealed. 


\section{Product Communication}

Product is the premise of marketing communication as the most essential element of marketing mix (Stone and Desmond, 2007: 226). The product components, which are considered as two main components, concrete and abstract, play an active role in differentiation in the market. Each component has a separate function within the scope of product communication. Concrete components are: size, features, color, durability, package and liking. Abstract components are classified as style, quality, image, prestige, guarantee and brand name (William, et al., 2009; 202). There are some decision stages in product communication. A product must have concrete and abstract components before getting capital value. The "product" in its raw form is processed through many stages and presented to the market. Obligations in product formation also allow the product to communicate (Clark and Wheelwright, 1993: 42-43). As can be seen from the shelves, especially in the retail sector, it is seen that the competition issue has reached to severe dimensions. Product management in the retail sector is very difficult and complex. The location of products in a store, shelf arrangement of products and their display with other products require an idea-oriented placement. Placement techniques by style, color, price, vertical placement and product weight are decided by brands and retailers according to many parameters. Product placement planning is also made according to criteria such as planned/unplanned purchase and featured product/complementary product (Ustaahmetoğlu, 2013: 137). In retailing management, issues such as shelf arrangement, shelf space, and spaces between shelves affect consumer preferences. Here, the main point is to provide convenience to customers. Nowadays, creating a suitable shopping environment where consumers can easily find what they want has become a problem for businesses. For businesses, shelf space management should be effectively implemented to help customers easily find the product they want, and this should no longer be a problem. Planning process should be carried out according to the access possibilities of customers. A hygienic atmosphere which is in accordance with the eye level of customers and taking into account the height, considering the customers according to each age group, and where similar product categories are in the same area and customer density is not ignored should be created. Customers should be able to walk between stands and see products easily (Özcan ve Esnaf, 2010: 56-58; Ustaahmetoğlu, 2013: 116-136; Fettahlıoğlu, 2014: 28-31; Bozpolat, 2017: 98-99).

Product package is of great importance for creating visual appeal to consumers and thus building trust.A good package is known to be effective in purchasing products. When products enter our homes, they should make sense especially through their package. The products that are known for their package provide confidence to the consumer when they are seen on the shelves among other products. This has a positive effect on repurchase (Baydaş ve Yaşar, 2018: 51-65). According to the researches, consumers are more sensitive about package especially when buying food products. Today, the use of package has become a means of communicating the benefits of concrete and abstract product to the consumer beyond being a material protecting the product (Ampuero and Vila, 2006: 100; Robertson, 2006: 44-46; Dilber, vd., 2012: 186). Consumer first meets the package of the product during shopping. There is a view that the gross viewing rate of a package in a shelf will be higher than the advertisement of the product, and that it can reach more effective dimensions than an advertisement (Twedt, 1968: 61). The unlimited dialogue that the package establishes with the consumer turns into a stronger communication when combined with advertising (Stone and Desmond, 2007: 322; Düz, 2012: 22-23; Wansink, 1996: 1-2).

\section{Product Communication in Consumer Trust}

The focus of a trusted brand is the consumer.Brands that protect consumer interests and prioritize them reflect a sense of security for the consumer. The consumer comes closer to the trust when $\mathrm{s} / \mathrm{he}$ is satisfied with the brand (Ha ve Perks, 2005: 443). Sense of trust is a value that should not be lost for brands. Other brand components are affected when the brand experiences any problems (Urde vd., 2007: 15-16). There is a high level of significant relationship between brand trust and brand image (Anwar vd., 2011: 76-77). Product features provide consumer trust for the consumer in purchase preferences (Kotler and Gertner, 2012: 250; Amin, vd., 
2015: 56-94). It is the effect of product components that drive the consumer into action during the shopping process. The consumer is influenced by the features of the product, evaluates and begins to interpret it. As a result, consumers tend to buy products that they believe, prefer, value and that increase their trust level (Dodds, 2002, 1-14; Anwar vd., 2011: 73-79).

Effective product planning is required to achieve a reliable communication dimension. The product should be renewed in line with rapidly changing market opportunities. After a product is put on sale, its performance should be monitored and its position in the product range should be continuously reviewed and necessary updatesshould be made (Varley, 2014: 216). The product attracts the consumer's attention in terms of the qualities it contains. The perception of quality is very important in the product evaluation process. The quality and durability of the product symbolize a safe product. Communication components such as brand name play an important role in product evaluation (Dodds, 2002: 10). When blended with a good product experience, high quality and a strong sense of trust, it enhances the competitive advantage of brands in the market (Çelebi, 2009: 1021-1045). The concrete and abstract features of the product provide a variety of options for positioning the brand. A product should provide with advantages for both brand and consumer. Presenting a reality close to consumers' feelings and combining it with the product is very attractive for brands. If the consumer can find the features they are looking for in a product, this motivates the consumer for product reliability (Shimp and Andrews, 2013: 141-143).

Identifying the product components that build consumer trust and the points that support purchasing constitutes the starting point of the issue. From this point of view, the main purpose of the study is to determine which product and product package properties are effective on the consumer. In order to realize this main purpose, the following points are considered:

\section{Research Questions}

R1: What is the relationship between product communication and consumer trust?

R2: Does product package affect consumers' trust in the product?

R3: Do the trusting dimensions of product communication affect brand trust?

R4: Does the trust dimension developed in the context of product communication differ according to the demographic characteristics of consumers?

\section{Method}

\subsection{Subject and Purpose of the Research}

The subject of the research is to examine the relationship between product communication and consumer trust. It is aimed to question the role of product communication dimensions, namely the concrete and abstract components of the product, especially product package, in consumer trust. The construct in this study is designed to relate the relationship between product communication and trust factor according to their dimensions. The independent variable in the study is product communication, and the dependent variable is trust. It is aimed to reveal the direction and significance level of the relationship between the two variables.

\subsection{Population and Sample of the Research}

The population in the study is the consumers who buy products from supermarkets in Turkey. This research was applied to the supermarket consumers. The sample of the study consists of consumers who shop at a local supermarket in the city center of Bartın. In the supermarket where the research is conducted, an average of 1000 people shop daily. Sample size was determined as 500 consumers. In sampling, easy sampling method which is one of the non-random sampling methods was used. In this study, field research was conducted to collect data systematically. A study was planned in which data were collected by survey technique. A survey in which faceto-face interview method was used was conducted. 
The following hypotheses were tested:

H1: There is a significant relationship between product communication and consumer trust factor.

H2: The package of the product plays a role in building trust in the consumer.

H3: As trust in product communication and package increases, trust in the brand increases.

H4: The trust developed in the context of product communication varies according to the demographic characteristics (H4.1.Gender, H4.2.Age, H4.3.Income status, H4.4.Education status, H4.5.Marital status, H4.6. Frequency of shopping, H4.7. Monthly shopping budget, H4.8. Number of household) of consumers.

\subsection{Scale of the Research and Preparation of the Survey Form}

The survey consists of three parts. Based on the literature review, the questions in the scales were adapted for the purposes of the research. The 13-item questions in the first part of the survey are aimed at determining brand trust. The questions in the second part are collected under a title and consist of 30 items. In this part, there are contents for product communication. These questions are intended to test trust in the product and package. In the third and the last part of the survey, there is a demographic information section and there are 9 questions. In addition, expert opinions on the advertising literature and relevant evaluations are included. In the study, "Five-Point Likert Scale" was used: (1: Strongly Disagree, 2: Disagree, 3: Hesitant, 4: Agree, 5: Strongly Agree.)

\subsection{Brand Trust Scale}

In this study, a scale developed by Delgado-Ballester, Munuera-Aleman and Yague-Guillen (2003: 35-53) is revieved. This brand trust scale consists of eight variables. Also, reliability and intention/s are discussed in two aspects. As a result of the brand confidence scale, consumer trust criteria are determined for the product they purchase.

The first aspect related to the mentioned scale is brand reliability. Here the brand meets the expectation and has a trusted quality. Therefore, brand trust refers to an area where the customer satisfaction scale should be kept high while meeting the needs and demands of the consumer. The second dimension is brand intentions. This means that the brand fulfills its responsibilities towards consumers. It is to believe that the brand will act in the interest of the consumer in any problem. The brand should reach such a point with its activities that it should reflect to the consumer that it has made every effort for him (Delgado-Ballester, Munuera-Aleman ve YagueGuillen, 2003: 35-53; Turgut, 2014: 31; Topçuoğlu, 2016: 64-65; Kalyoncuoğlu, 2017: 384-387).

The statements regarding the brand trust scale mentioned in the study of Delgado-Ballester, MunueraAleman and Yague-Guillen (2003), titled 'Development and Validation of a Brand Trust Scale' are as follows:

- The brand $\mathrm{X}$ is a brand that meets my expectations.

- I trust the brand $X$.

- I think the brand $X$ would not let me never be disappointed.

- The brand $X$ ensures customer satisfaction.

- I think that the brand $X$ will be right and honest in solving any problems with the product.

- If I encounter a problem, I trust the brand $X$ will solve my problem.

- I think the brand $X$ will do its best to please me.

- If I have any problems with the product, the brand $X$ will compensate.

Delgado-Ballester, Munuera-Aleman and Yagüe-Guillen (2003) accessed randomly to 272 participants through a telephone interview while planning the scale-related study.Participants were asked which brand 
deodorant they used. At the end of the study started with an adventure of 16 items, an eight-item two-factor brand trust scale has emerged.

This scale was then validated and approved by the studies titled "Applicability of a Brand Trust Scale across Product Categories: A Multigroup Invariance Analysis" by Delgado-Ballester (2004: 573-591), and "Does Brand Trust Matter to Brand Equity?" by Delgado-Ballester and Munuera-Aleman (2005: 187-195). In this study, 5 items were added to the scale and adapted as follows:

1. As my trust in $X$ product package increases, I am willing to pay more money than others.

2. As my trust in $X$ product package increases, my satisfaction with the product increases.

3. As my trust in $X$ product package increases, I buy more often than others.

4. As my trust in $X$ product package increases, I would recommend it to others.

5. As my trust in $\mathrm{X}$ product package increases, my trust in the brand increases.

\subsection{Product Communication Scale}

In the second part of the survey, it is aimed to reveal which dimensions the consumer considers regarding the product package. In the literature, a scale of product communication criterion which is suitable for the purpose of the research has not been found. For this reason, a trial scale development process was carried out. It is aimed to determine the consumer's trust in the product and package during the purchasing stage and the features that help to build this trust.An item pool was created after a literature review related to this situation was performed. It was ensured that the items were clear and understandable.

A question title was obtained like "The following features of the product $\mathbf{X}$ package increase my trust in the product and brand". According to this question title, variables related to product communication, ie draft scale, are composed of 30 items.

\subsection{Preliminary Study and Final Version of the Survey Form}

In order to determine the product category that will be the subject of the research, the preliminary study is considered to be a correct step. Accordingly, the relevant product categories in the supermarket where the application was conducted are determined as follows: Consumers were asked to select one of the most relevant product categories they buy most in their current and previous market shoppings. Thus, the product category most favored by consumers in supermarket shopping was determined. As a result of the exploratory research, it was determined that the product category that consumers frequently prefer is "biscuit and chocolate product category (snack products)" (30/9).

After the pilot research on the brand trust scale, reliability analysis was applied to determine the internal consistency of the scale and Alpha coefficient was found to be $\mathbf{0 . 8 2 2}$. The responses to the items are expected to have a positive correlation between the items and the scale total. It is seen that Item total correlation of items 1 and 2 is low and Alpha value increases when item is deleted. Therefore, items 1 and 2 were excluded from the scale. Alpha coefficient was found to be $\mathbf{0 , 8 4 3}$. Thus, it is seen that the values of the items are at an acceptable level. The brand trust scale was applied on the real sample (500 participants) as 11 items.

After the pilot research on the product communication scale, reliability analysis was performed to determine the internal consistency of the scale. Alpha coefficient was found to be $\mathbf{0 , 5 8 1}$. From the scale, items $4,5,8,9,11,12,14,17,21,22,26$ have low total item correlation and Alpha value increases when item is deleted. When these items were excluded from the scale, Alpha coefficient was found to be $\mathbf{0 , 7 5 7}$. The values of the items were found to be at an acceptable level and the product communication scale was applied on the real sample (500 participants) as 19 items. 
In addition, this pilot study was carried out to prevent mistakes during the application and to check whether the questions were understood. With the preliminary study, the questions to be included in the survey were finalized.Some unclear variables were excluded. Thus, the survey form was finalized. After the pilot study conducted on 30 people, according to the validity and reliability results of the scale questions, the questions in the first part of the survey included 11 items and the 30 items in the second part of the survey took place in the survey as 19 items. The final version of the survey questions is given in Table 1 and Table 2.

\subsection{Statistical Analysis}

The data obtained from the study were analyzed by using SPSS (Statistical Package for Social Sciences) for Windows 22.0 program. Factor analysis was applied during the evaluation stage of the scales. The purpose of the factor analysis is to determine the construct validity of the scale, to reduce the number of variables and to reveal the relationships between the variables.For this reason, exploratory factor analysis was applied. Number, percentage, average and standard deviation were used as descriptive statistical methods during the evaluation of the data. The t-test was used to compare quantitative continuous data between two independent groups, and the Anova test (One-way) was used to compare quantitative continuous data between more than two independent groups. After the Anova test, Scheffe test was used as a complementary post-hoc analysis to determine the differences. Pearson correlation and regression analysis were used between the continuous variables of the study.

\section{Results}

\subsection{Brand Trust Scale Factor Structure}

In order to calculate the reliability of the 11 items, the internal consistency coefficient "Cronbach Alpha" was calculated. The overall reliability of the scale was found to be high as Alpha=0,848. Explanatory (exploratory) factor analysis was applied to reveal the construct validity of the scale. As a result of the Bartlett test $(p=0.000$ $<0.05)$, it was found that there was a relationship between the variables included in the factor analysis. As a result of the test $(\mathrm{KMO}=0.833>0,60)$, the sample size was found to be sufficient for the application of factor analysis.In the factor analysis application, varimax method was chosen and the structure of the relationship between the factors remained the same. As a result of factor analysis, variables were collected under 3 factors and total explained variance was $69.528 \%$. It was found that the brand trust scale was a valid and reliable tool according to the alpha found and the variance value explained for reliability. The factor structure of the scale is seen below (Table 1).

Table 1. The Factor Structure of the Brand Trust Scale

\begin{tabular}{|c|c|}
\hline Dimension & Factor Load \\
\hline \multicolumn{2}{|l|}{ Trust in Product (Eigenvalue = 1,038; Explained Variance = 15,225; Alpha =0,724) } \\
\hline 1. I think the brand $\mathrm{X}$ would not let me never be disappointed. & 0,762 \\
\hline 2. The product $X$ meets customer satisfaction & 0,870 \\
\hline \multicolumn{2}{|l|}{ Brand Intention and Reliability (Eigenvalue=2,135; Explained Variance =26,926; Alpha=0,865) } \\
\hline $\begin{array}{l}\text { 3. I think that the brand } \mathrm{X} \text { will be right and honest in solving any problems with the } \\
\text { product. }\end{array}$ & 0,743 \\
\hline 4. If I encounter a problem, I trust the brand $X$ will solve my problem. & 0,824 \\
\hline 5. I think the brand $\mathrm{X}$ will do its best to please me. & 0,845 \\
\hline 6. If I have any problems with the product, the brand X will compensate. & 0,793 \\
\hline \multicolumn{2}{|l|}{ Trust in Package (Eigenvalue = 4,475; Explianed Variance =27,377; Alpha=0,809) } \\
\hline $\begin{array}{l}\text { 7. As my trust in the package of product } X \text { increases, I am willing to pay more money } \\
\text { than others. }\end{array}$ & 0,534 \\
\hline
\end{tabular}




\begin{tabular}{|l|c|}
\hline $\begin{array}{l}\text { 8. As my trust in X product package increases, my satisfaction with the product } \\
\text { increases. }\end{array}$ & 0,769 \\
\hline 9. As my trust in X product package increases, I buy more often than others. & 0,854 \\
\hline 10. As my trust in X product package increases, I would recommend it to others. & 0,830 \\
\hline 11. As my trust in X product package increases, my trust in the brand increases. & 0,778 \\
\hline Total Variance $\mathbf{6 9 . 5 2 8 \% ; ~ G e n e r a l ~ R e l i a b i l i t y ~ ( A l p h a ) ~} \mathbf{0 . 8 4 8}$ \\
\hline
\end{tabular}

The original factor structure of the brand trust scale was used for the questions about "trust". However, due to the adaptation of the scale to the study, a different formation emerged than the original factor structure of the scale. A new factor naming has been made for these 3 factors that have emerged as a result of factor analysis by evalauting the original factor structure of the scale and considering the content of the variables, with regard to the subject of the research.

\subsection{Product Communication Scale Factor Structure}

Explanatory factor (exploratory factor analysis) analysis method was used to determine the construct validity of the scale. As a result of the Bartlett test $(p=0.000<0.05)$, it was found that there was a relationship between the variables included in the factor analysis. As a result of the test $(\mathrm{KMO}=0.727>0.60)$ it was determined that the sample size was sufficient for the application of factor analysis. In the factor analysis application, varimax method was chosen and the structure of the relationship between the factors remained the same. As a result of factor analysis, the total explained variance of the variables was $62.239 \%$, and was grouped under 4 factors. The overall reliability of the scale was found to be high as Alpha $\mathbf{= 0 . 7 1 7}$.

Six items were excluded from the scale, because they have a negative effect on internal consistency and factor load is low. These items are 5, 7, 13, 15, 16, 17. These items are indicated as follows: "5) Texture (package material, quality etc.), 7) Emphasizing product warranty and durability, 13) Being at hand-level on the market shelf, 15) Being among other products in the same category, 16) Writing the date of production and expiry date on the package clearly, 17) Barcode, origin, ingredients are important and trust element."

Product communication scale was found to be a valid and reliable instrument according to the alpha and explained variance value of the scale. "Product communication scale" which has a total reliability of 0,717 and consisting of a total of 13 variables was obtained.

Table 2. The Factor Structure of the Product Communication Scale

\begin{tabular}{|l|c|}
\hline \multicolumn{1}{|c|}{ Dimension } & Factor Load \\
\hline $\begin{array}{l}\text { Dimension of concreteness } \\
\text { (Eigenvalue = 3,140; Explained Variance = 20,970; Alpha = 0,830) }\end{array}$ \\
\hline 1. Color & 0,759 \\
\hline 2. Shape & 0,904 \\
\hline 3. Size & 0,863 \\
\hline 4. Odor & 0,719 \\
\hline $\begin{array}{l}\text { Attractiveness } \\
\text { (Eigenvalue = 1,446; Explained Variance = 13,622; Alpha = 0.610) }\end{array}$ \\
\hline 6. Expressing more visually without writing & 0,804 \\
\hline 8. Including celebrities, advertising face or mascot in the product package & 0,595 \\
\hline 9. Remarkably colored package & 0,689 \\
\hline $\begin{array}{l}\text { Strong Company Message and Perceived Ease of Use } \\
\text { (Eigenvalue = 1,260; Explained Variance = 11,908; Alpha = 0,614) }\end{array}$ \\
\hline $\begin{array}{l}\text { 10. Ease of use of the package (opening, closing, storage, being protective, } \\
\text { functionality) }\end{array}$ & 0,854 \\
\hline
\end{tabular}




\begin{tabular}{|l|c|}
\hline $\begin{array}{l}\text { 11. Emphasizing the strength of the manufacturer as well as the brand name in the } \\
\text { package }\end{array}$ & 0,732 \\
\hline $\begin{array}{l}\text { Special Communication Dimension } \\
\text { (Eigenvalue = 2,245; Explained Variance } \mathbf{~ 1 5 , 7 3 9 ; ~ A l p h a ~ = ~ 0 , 6 0 9 ) ~}\end{array}$ & \\
\hline 12. Constant renewal of package & 0,636 \\
\hline 14. Selling in a special place alone in the market & 0,646 \\
\hline $\begin{array}{l}\text { 18. I see the product package in the advertisements of the brand frequently and the } \\
\text { package is emphasized in the advertisements. }\end{array}$ & 0,625 \\
\hline $\begin{array}{l}\text { 19. Special communication activities related to the product in store (advertising, } \\
\text { supervision, etc.) }\end{array}$ & 0,710 \\
\hline Total Variance $\mathbf{6 2 . 2 3 9 \% ; ~ O v e r a l l ~ R e l i a b i l i t y ~ ( A l p h a ) = 0 . 7 1 7 ~}$ \\
\hline
\end{tabular}

4 factor structure has emerged in the product communication dimension prepared based on the concreteness / abstractness situations and package elements of the product. Twedt's (1968) VIEW (visible, informative, emotionally appealing, workable) formula and then "product components" classification of Odabaşı and Oyman (2001: 226) were used to name factor dimensions, in the subject of product communication. Naming was carried out according to the content and features of the variables in the scale.

\section{Brand Trust Average Scores of the Participants (N: 500)}

- Participants' trust in the product is very high 4,351 $\pm 0,636$ (Min=1; Max=5),

- Brand intention and reliability average are high 4,049 $\pm 0,691$ ( $M i n=2 ; M a x=5)$,

- Average trust in package is high $4,188 \pm 0,664$ ( $\operatorname{Min}=1.2 ; \operatorname{Max}=5$ ),

- The overall scale brand trust average was found to be high as 4,167 $\pm 0,524(\operatorname{Min}=2.55 ; \operatorname{Max}=5)$.

Product Communication Average Points of the Participants (N: 500)

- Participants' concreteness dimension average is very high 4,298 $\pm 0,750$ ( $M i n=2 ; M a x=5$ ),

- Average attractivenessis high 3,561 $\pm 0,985$ ( $\operatorname{Min}=1 ; \operatorname{Max}=5$ ),

- Average of strong company message and perceived ease of use is very high 4,341 $\pm 0,782$ ( $M i n=1$; $M a x=5$ ),

- Special communication dimension average is high 3,436 $\pm 0,837$ ( $M i n=1 ; M a x=5)$

- Product communication, overall scale average was found to be high as $3,869 \pm 0,536$ ( $\operatorname{Min}=1.77 ; \operatorname{Max}=5)$.

\subsection{The Role of Trust in Product Communication}

Regression analysis to determine the cause-effect relationship between product communication and brand trust was found to be significant $(F=63,758 ; p=0,000<0.05)$. The total change in trust at the general scale level is explained at the rate of $11,2 \%$ by product communication $\left(R^{2}=0,112\right)$. When we look at the general table, product communication increases brand trust level $(\beta=0,330)$. Therefore, the hypothesis H1: "There is a significant relationship between product communication and consumer trust" is confirmed here. At the same time, when the significance level of this hypothesis is considered at the general scale level, it demonstrates the strength of the correlation between product communication and brand trust $(r=0.337$ positivity, $(p=0,000<0.05)$. Product communication and trust factor were found to be statistically significant. In addition, with the following explanations, we see that product communication sub-factors increase trust level in general. There is a result supporting the $\mathrm{H} 1$ hypothesis.

Regression analysis conducted to determine the cause-effect relationship between concreteness dimension, attractiveness, strong company message, perceived ease of use, special communication dimension and trust in product was found significant $(\mathrm{F}=11,818 ; \mathrm{p}=0,000<0.05)$. Total change in the level of trust in product is explained at the rate of $8 \%$ by independent variables $\left(R^{2}=0,080\right)$. 
Regression analysis conducted to determine the cause-effect relationship between concreteness dimension, attractiveness, strong company message, perceived ease of use, special communication dimension and trust in brand was found significant $(F=24,053 ; p=0,000<0.05)$. Total change in the level of trust is explained at the rate of $15.6 \%$ by concreteness dimension, special communication dimension, attractiveness, strong company message, perceived ease of use $\left(R^{2}=0,156\right)$.

\section{The Impact of Product Communication Sub-dimensions on Trust in Package}

Regression analysis conducted to determine the cause-effect relationship between concreteness dimension, attractiveness, strong company message, perceived ease of use, special communication dimension and trust in package was found significant $\quad(F=22,728 ; p=0,000<0.05)$. Total change in the level of trust in product is explained at the rate of $14.8 \%$ by independent variables $\left(R^{2}=0,148\right)$. The dimension of concreteness increases the trust in the package $(\beta=0,196)$. Strong company message and perceived ease of use increase trust in package $(ß=0,143)$. Special communication dimension increases trust in package $(ß=0,179)$.

Although the dimension of attractiveness did not affect the level of trust in package $(p=0.438>0.05)$, the regression analysis showed that the overall level of "trust in package" was significant $(F=22,728 ; p=0,000<0.05)$. Therefore, the hypothesis H2: "The package of the product is important for consumers to build trust in their purchasing preferences and plays a decisive role." is confirmed. Here, statistically, it is possible to mention the importance and determining feature of the product package. As a result of correlation analysis, $r=0.346$ positive $(p=0,000<0.05)$, statistical significance level was observed between product communication and attitude towards package.

\section{Effect of Product Communication Sub-dimensions on Brand Intention and Reliability}

Regression analysis conducted to determine the cause-effect relationship between concreteness dimension, attractiveness, strong company message, perceived ease of use, special communication dimension and "brand intention and reliability" was found significant $(F=9,983 ; p=0,000<0.05)$. Total change in the level of "brand intention and reliability" is explained at the rate of $6.7 \%$ by independent variables $\left(R^{2}=0,067\right)$. Therefore, the hypothesis H3: "As trust in product communication and package increases, confidence in the brand increases" is confirmed.

The dimension of concreteness increases the level of "brand intention and reliability" $(ß=0,154)$. Strong company message and perceived ease of use increase "brand intention and reliability" $(ß=0,138)$. When the special communication dimension $(p=0.822>0.05)$ and the attractiveness dimension $(p=0.063>0.05)$ are examined, it has no effect on the brand intention and reliability. However, when we look at the general level after regression analysis $(F=9,983 ; p=0,000<0.05)$, we see that the H3 hypothesis is confirmed.

Furthermore, when the statistical significance level of this situation is examined, a positive and significant relationship is found between product communication and "brand intention and reliability" dimension $(r=0.228$ positive $(p=0.000<0.05))$. Product communication has been found to increase brand trust at the general scale level. When we look at the beta value we can see that this is confirmed $(\beta=0,330)$. Therefore, the $\mathrm{H} 3$ hypothesis is supported.

\subsection{Demographic Characteristics of Participants}

- According to gender, majority of the participants were female (Number of female is 262 (52.4\%) and number of male is 238 (47.6\%).

- The majority in the distribution by age is between 18 and 30 . (100 participants (20.0\%) are 25 and below, 100 participants (20.0\%) are between $26-30)$

- According to the income, the majority was between $1500 T L-2000 T L$. (201 participants $(40,2 \%)$ are $2000 T L$ and below.)

- According to the education level, the majority are at the levele of associate, bachelor and master. (249 participants $(49,8 \%)$ are from college and above.) 
- According to marital status, the majority is married. (307 participants $(61,4 \%)$ are married and 193 participants (38,6\%) are single.)

- According to the frequency of shopping, the participants do the grocery shopping maximum several times a week. (188 participants (37,6\%) shop several times a week, 108 participants (21,6\%) shop every day.)

- The majority varies between 100TL and 500TL according to monthly grocery spending. (320 participants $(64,0 \%)$ are 500TL and below, 154 participants $(30,8 \%)$ are 501-1000TL.)

- The participants have 4 households. (157 participants $(31,4 \%)$ have 4 households and 155 participants $(31,0 \%)$ have 3 households.)

\section{Comparison of Brand Trust Scores by Descriptive Characteristics}

Participants' trust in the product, brand intention and reliability, trust in package and brand trust scores do not differ significantly according to "gender, age, income, marital status, shopping frequency, monthly grocery spending amount and household number" variables $(p>0,05)$. Therefore, the hypotheses $\mathrm{H} 4.1, \mathrm{H} 4.2, \mathrm{H} 4.3, \mathrm{H} 4.5$, H4.6, H4.7, H4.8 were rejected.

According to the "educational status" of the participants, trust in product scores differ significantly $\mathbf{F}_{(\mathbf{3}}$, $496)=3,517 ; p=0,015<0.05)$. The reason for the difference is that the scores of "trust in product" of the primary school students $(\bar{x}=4,425)$ are higher than the scores of "trust in product" of the secondary school students $(\bar{x}=$ $4,058)$. This is because the scores of "trust in product" of the high school students $(\bar{x}=4,390)$ are higher than the scores of "trust in product" of the secondary school students $(\bar{x}=4,058)$. This is because the scores of "trust in product" of the college students $(\bar{x}=4,364)$ are higher than the scores of "trust in product" of the secondary school students $(\bar{x}=4,058)$. Therefore, H4.4: The hypothesis "The confidence dimension developed in the context of product communication varies according to the education level of the consumers" is confirmed. Participants' brand intention and reliability, trust in package and brand trust scores do not differ significantly according to educational status variable $(\mathrm{p}>0.05)$.

\section{Comparison of Product Communication Scores by Descriptive Characteristics}

- The scores related to the "special communication dimension" by gender differ significantly. Men's scores on the special communication dimension are higher than that of women.

- There was a significant difference in terms of product communication scores and attractiveness factor according to marital status. The product communication scores of the singles and the attractiveness factor scores were found to be higher than the married ones.

- Special communication dimension scores and product communication scores differ significantly according to shopping frequency.

- The dimensions where product communication scores differ according to monthly grocery spending are as follows: concreteness dimension, strong company message and perceived ease of use.

- Product communication scores do not differ significantly according to age, number of households, income and education level.

\section{CONCLUSIONS}

According to the results of the research, it is seen that there is a significant relationship between product communication and brand trust (trust factor). According to the findings, the package has an impressive power on consumers. It has been confirmed that the size of the package is a decisive factor for consumers. Consumers pay attention to the features of the product and package during the shopping process, and they associate this with safe shopping. It is clarified with this research that consumers have an active perception in the point of trust in brand, product and package.

If we put forward a summary of the evaluation of the findings, the following issues arise:

- The concrete properties of the product (color, shape, size, smell) have been found to be effective in building trust in the brand, product and package. 
- The relationship between the attractiveness of the package and the fact that it is in the forefront and brand trust in general has been found to be positive and significant. However, it is determined that it does not affect the level of trust in brand, product and package statistically.

- As a result of the special communication activities related to the product in the shopping environment and the emphasis on product package, a significant relationship was established with brand trust in general level. It increases the level of trust in package and the level of trust among consumers in brand criterion. However, on the factor basis, it has been found that special communication dimension did not affect "the brand intention and reliability" and "trust in the product".

- The strong company message and the perceived ease of use of the package, which are emphasized at the point of product communication, affect the trust in brand, product and package and increase the level of trust.

If we consider the concreteness dimension of the product, it is seen that the participants answered positively at a very high level for color, shape, size and smell. Consumers believe that these features of the product package they choose build trust. These results of the research indicate that brands should pay special attention to the color, shape, size and smell of the product and package during the product development process.

The fact that the product package is expressed more visually without writing and that the package is remarkable in color has a high level of participation. The comment here is that consumers tend to packaged products that are plain but remarkable.According to another statement which is evaluated within the dimension of attractiveness, the presence of celebrities or advertising face and mascot in the product package received moderate level of participation from consumers. The point stated here is that consumer liking level, brand communication activities and brand awareness have an impact on consumers. The use of celebrities by brands, mascot creation and advertising face preferences were evaluated by the consumer and this created an emotional weight.In the context of the results of the research, the attractiveness of product package is a factor affecting the trust of consumers.

When the participants' responses and findings regarding the strong company message and perceived ease of use factor were examined, the ease of use of the package and the emphasizing the strength of the manufacturer firm as well as the brand name in the package have received very high level of participation. Concerning the ease of use of the package, that is to say, it is easy to open and close, it is easy to store, at the same time, the protective function of the package is high; thus, it is concluded that the packages containing functional features have strong communication sound. The fact that consumers see brand and company names on the package for the product they prefer in their shopping is another feature that builds trust for the consumer.

When the responses of the participants to the special communication dimension were evaluated, it was observed that there was a moderate level of participation in the constant renewal of the package and special communication activities related to the product in a store. The fact that these two expressions received participation at a medium level brings both advantageous and disadvantageous comments. The fact that the product package is constantly being renewed can be a problem if the necessary conditions are not met when consumers search for the desired product. In other words, if the product relocation process has been carried out or any package is renewed, it is not possible for the brand to achieve success unless supported by these communication efforts. The process of change and renewal related to the product and package becomes meaningful for the consumer if it is supported by the communication activities of the brands. The positive side of the package renewal process reveals that the brand actually works hard, making the necessary improvements for its consumers and shows an innovative attitude. Conducting special communication activities related to the product within the store is also relevant to the time spent by the consumer in the store. It is concluded that instore communication activities affect product-based gains and consumer trust.

When the responses of the participants to other statements about the special communication factor were examined, the fact that the product was sold in a special place in the market alone and that the product package was more visible than the advertisements of the brand and the emphasis on the package in the 
advertisements had a high level of participation. Communication activities and in-store stand movements, which are believed to gain originality to the product attract the attention of consumers. Displaying the product alone in the market attracted the attention of the consumer and according to the results of the research, it has managed to become a trust element. Emphasis on package in advertisements indicates that the consumer is offered a product and package supported by communication efforts. According to the results of the research, the fact that package of the product is displayed at the forefront and the emphasis on the package with the communication efforts seem to have gained the trust of the consumer.

As a result, this study sheds light on the trust sensitivity of consumers in the context of product communication. In other words, it refers to the shopping habits of consumers and the points they pay attention to on the basis of product/ package. Some features and functions of the product package affect consumers' trust in the product and therefore the brand. Consumers do not only fulfill their basic needs when buying a product. Because, "need" is a concept that is hard to concretize.Consumers are influenced by the level of branding and the product management process concerning a product. In the same direction, it is undeniable that consumers affect all processes within the framework of marketing communication, branding and product communication.Today, a product preferred by the consumer is beyond meeting the physiological needs. Keeping up with the changing market volume is the ultimate goal of enterprises. This is the same in the retail sector. It is very important to meet the changing needs gap of consumers and to follow the developing trends in the retail sector. With this study, it is underlined how variable the product management line is and at this point it is necessary to analyze the consumer well.

\section{REFERENCES}

Amin, M.; Imran, M.; Abbas, N.; Rauf, U. (2015). Impact of the Product Packaging on the Consumer Buying Behavior. Journal of Marketing and Consumer Research, ISSN 2422-8451 An International Peerreviewed Journal, Vol.16.

Ampuero, O., Vila, N. (2006). Consumer Perceptions of Product Packaging. Journal of Consumer Marketing, 23 (2), 100-112.

Anwar, A.,Gulzar, A., Sohail, F. B. and Akram, S. N. (2011). Impact Of Brand Image, Trust and Affect On Consumer Brand Extensıon Attitude: The Mediatıng Role Of Brand Loyality. International Journal of Economics and Management Sciences, 1 (5), 73-79.

Baydaş, A., Yaşar, M. E. (2018). Ambalajın Satın Alma Davranışı Üzerindeki Etkisinin Belirlenmesine Yönelik Ampirik Bir Çalışma. Bingöl Üniversitesi Sosyal Bilimler Enstitüsü Dergisi, 8 (16), 49-68.

Bozpolat, C. (2017). Mağaza Atmosferinin Tüketici Tercihindeki Önemi. The Journal of Social Science. 1 (1), $94-$ 103.

Clark, K. B., Wheelwright, S. C. (1993). Managing New Product and Process Development: Text Cases. New York: Free Press.

Çelebi, S. I. (2009). The Importance Of The Truth Effect And Source Credibility For New Fmcg Advertising. Journal of Yasar University, 4(13), 1021-1045.

Delgado-Ballester, E., Munuera-Aleman, J.L., Yague-Guillen, M.J., (2003). Development and Validation of a Brand Trust Scale. International Journal of Market Research, 45 (1), 35-53.

Delgado-Ballester, E., Munuera-Alemán, J.L., (2005). Does Brand Trust Matter To Brand Equity?. Journal of Product \& Brand Management, 14 (3), 187-196. 
Delgado-Ballester, E., (2004). Applicability Of A Brand Trust Scale Across Product Categories: A Multigroup Invariance Analysis. European Journal of Marketing, 38 (5/6), 573-592.

Dilber, F.; Dilber, A.; Karakaya, M.; Gürkan, H. (2012). Gıdalarda Ambalajın Önemi ve Tüketicilerin Satın Alma Davranışlarına Etkisi (Karaman ili Örneği). Gümüşhane Üniversitesi Illetişim Fakültesi Elektronik Dergisi. 3, (159-190).

Dodds, William B. (2002). The Effects of Perceived and Objective Market Cues on Consumers' Product Evaluations. Marketing Bulletin, 13 (2), 1-14.

Düz, N. (2012). Ambalaj-Reklam iliş̧kisi Ve Tasarım Eğitimindeki Yeri. Batı Anadolu Eğitim Bilimleri Dergisi (BAED), Dokuz Eylül Üniversitesi Eğitim Bilimleri Enstitüsü, İzmir-Türkiye ISSN 1308 - 8971 (online), 3 (6), 19-52.

Fettahlıŏlu, S. (2014). Tüketicilerin Mağaza Atmosferinden Etkilenme Düzeylerinin Demografik Faktörler Açısından incelenmesi. Akademik Araştırmalar ve Çalışmalar Dergisi. 6 (11), 27-40.

Ha, Hong-Youl., Perks, H. (2005). Effects Of Consumer Perceptions Of Brand Experience On The Web: Brand Familiarity, Satisfaction and Brand Trust. Journal of Consumer Behaviour, 4 (6), 438-452.

Kalyoncuoğlu, S. (2017). Markaya Duyulan Güven Ile Marka Sadakati ilişkisinde Marka Aşkının Aracılık Rolü: Starbucks Markası Üzerine Bir Araştırma. Journal of Tourism and Gastronomy Studies. 5/4. 383-402.

Kotler, P., Gertner, D. (2012). Country As Brand, Product, And Beyond: A Place Marketing And Brand Management Perspective. 9 (4). 249-261.

Odabaşı, Y., Oyman, M. (2001). Pazarlama Iletişimi Yönetimi. İstanbul: MediaCat Yayınları.

Özcan, T., Esnaf, ş. (2010). Perakende Endüstrisinde Raf Alanı Tahsis ve Mağaza Yerleşim Optimizasyonuna Bütünleşik Bir Model Önerisi. İstanbul Üniversitesi Mühendislik Bilimleri Dergisi, 1, 55-63.

Robertson, G. L. (2006). Food Packaging: Principles and Practice. (Second Edition). London: Taylor \& Francis Group CRC Press.

Shimp, Terence A., Andrews, J. C.. (2013). Advertising Promotion and Other Aspects of Integrated Marketing Communications. (Ninth Edition). U.S.A.: South-Western Cengage Learning.

Stone, M. A., Desmond, J. (2007). Fundamentals of Marketing. (1. Baskı). New York: Routledge.

Topçuoğlu, F. (2016). Marka Tutumu ile Imajının Marka Değeri ve Güveni Yaratılmasındaki Rolü, Tüketicinin Satın Alma Niyeti Üzerindeki Etkileri. Doktora Tezi, Beykent Üniversitesi Sosyal Bilimler Enstitüsü, İstanbul.

Turgut, M.Ü. (2014). Marka Sevgisinin Marka Güveni, Olumsuz Bilgiye Karşı Direnç ve Tekrar Satın Alma Niyeti Çerçevesinde incelenmesi. Yüksek Lisans Tezi, Hacettepe Üniversitesi Sosyal Bilimler Enstitüsü, Ankara.

Twedt, D. W. (January, 1968). How Much Value Can Be Added Through Packaging? . Journal of Marketing, 32, 58-61.

Urde, M., Greyser S. A., Balmer, J. M. T. (2007). Corporate Brands With a Heritage. Brand Management, 15 (1), 4-19.

Ustaahmetoğlu, E. (2013). Mağaza Alanının Ürünlere Dağııımı. (Editörler: Erdoğan, Z. ve Özata, Z.). Perakendecilikte Ürün Yönetimi. (1.Baskı). Eskişehir: Anadolu Üniversitesi Yayınları, 116-140. 
Varley, R. (2014). Retail Product Management: Buying and Merchandising. (Third Edition). New York: Routledge. Wansink, B. (1996), Can Package Size Accelerate Usage Volume?, Journal of Marketing, 60, 1-14.

William, W., Sandra, M., Nancy, M. (2009). Advertising \& IMC Principles \& Practice, (9th Edition). Prentice Hall. 